ÉGYPTE

monde arabe

\section{Égypte/Monde arabe}

$3 \mid 1990$

Médiateur et métaphores 2

\title{
Crise du Golfe, annexe XI : Frères musulmans :
}

Communiqué $\mathrm{n}^{\circ} 3$

Liwâ' Al-Islâm, 21 septembre 1990

\section{OpenEdition}

Journals

Édition électronique

URL : https://journals.openedition.org/ema/1897

DOI : 10.4000/ema. 1897

ISSN : 2090-7273

Éditeur

CEDEJ - Centre d'études et de documentation économiques juridiques et sociales

Édition imprimée

Date de publication : 30 septembre 1990

Pagination : 258-259

ISSN : 1110-5097

Référence électronique

"Crise du Golfe, annexe XI : Frères musulmans : Communiqué n 3 », Égypte/Monde arabe [En ligne], 3 | 1990, mis en ligne le 08 juillet 2008, consulté le 07 juillet 2022. URL : http://journals.openedition.org/ ema/1897 ; DOI : https://doi.org/10.4000/ema.1897

Ce document a été généré automatiquement le 7 juillet 2022

Tous droits réservés 


\section{Crise du Golfe, annexe XI : Frères musulmans : Communiqué $\mathrm{n}^{\circ} 3$}

Liwâ' Al-Islâm, 21 septembre 1990

1 Les Frères musulmans ont publié un communiqué à propos de l'interdiction signifiée à la délégation de l'Alliance islamique de prendre part aux efforts de médiation entrepris par la délégation islamique mondiale pour contribuer à résoudre la crise du Golfe. Voici le texte du communiqué :

2 Louange à Dieu, Seigneur des deux mondes, et paix sur le plus noble des envoyés. Compte tenu de l'aggravation de la crise du Golfe, les associations islamiques dans le monde islamique - et à leur tête la confrérie des Frères musulmans et l'Alliance islamique en Égypte - se sont mutuellement invitées à déployer tous leurs efforts auprès des parties en conflit pour tenter d'éviter le déclenchement de la guerre et servir ainsi le bien de la nation.

3 Les confréries islamiques d'Algérie, de Tunisie, du Soudan, du Yémen, de Malaisie, de Turquie, du Pakistan, de Jordanie, d'Europe et d'autres pays ont convenu de se retrouver à 'Amman pour, de là, se rendre dans un premier temps à Bagdad puis en Arabie Saoudite et dans d'autres pays concernés, pour présenter une contribution populaire à la recherche d'une solution pacifique de la crise actuelle, solution qui devrait recueillir le consentement des parties en conflit et permettrait d'épargner à la région les malheurs d'une guerre destructrice, dont seul le Très-Haut connaît les terribles conséquences et qui ne profiterait qu'aux ennemis de la nation, avec à leur tête l'entité sioniste.

4 Le mardi 11 septembre 1990, l'ingénieur Ibrahîm Chukrî, président du Parti du Travail et leader de l'opposition, s'est rendu à l'aéroport international du Caire en compagnie du conseiller Muhammad Al-Ma'mûn Al-Hudaybî, président du groupe parlementaire des Frères musulmans, dans l'intention de s'embarquer pour 'Amman. À l'aéroport, les responsables de la sécurité ont arraché une page du passeport de chacun d'eux et prétendu ensuite que leurs passeports n'étant pas valides, ils ne pouvaient quitter le territoire. 
Le lendemain 12 septembre 1990, M. Muhammad Hâmid Abû-l-Nasr, guide suprême des Frères musulmans, accompagné de l'ingénieur Ibrahîm Chukrî muni d'un nouveau passeport, de M. Mustafâ Machhûr, adjoint du guide suprême et du conseiller Muhammad Al-Ma'mûn Al-Hudaybî, se sont rendus à l'aéroport international du Caire. Les policiers qui guettaient leur arrivée leur ont interdit l'accès du bâtiment sous prétexte qu'un problème s'opposait à leur départ.

6 Ces procédés étant contraires à la Constitution et aux usages de la jurisprudence, ces procédés contredisant, de plus, les affirmations réitérées en toutes occasions par le président Hosni Moubarak quant à la nécessité d'oeuvrer par tous moyens au règlement pacifique de la crise sans recourir à la confrontation militaire, nous ne pouvons que protester vigoureusement contre ces agissements, qui sont contraires aux libertés publiques et empêchent les leaders de mouvements populaires de s'acquitter du rôle qui leur incombe dans cette crise grave, au moment où nombre des États étrangers impliqués dans le conflit autorisent certaines personnalités non officielles à entrer en contact avec les parties adverses... Nous considérons les autorités ayant eu l'initiative de cette interdiction comme responsables des doutes qui entachent la crédibilité des affirmations du président Hosni Moubarak quant à la recherche d'une solution pacifique à la crise ; elles sont également responsables des conséquences que peut entraîner l'interdiction d'une démarche efficace, susceptible d'écarter les graves répercussions qu'une guerre dans la région ne manquerait pas d'avoir sur les intérêts arabes et islamiques, en contribuant .à réaliser les plans des ennemis de l'arabisme et del'islam.

Dieu est le guide vers le succès et le droit chemin...

8 Muhammad Hamdi Abu-l-Nasr, Guide suprême des Frères musulmans.

9 Ibrahim Chukî, président du Parti du Travail.

10 Le conseiller Al-Ma'mûn Al-Hudaybî.

11 M. Mustafa Machhûr.

12 M. Mustafâ Kâmil Murâd. 